\title{
Differences between the profiles of institutionalized elderly people and those on waiting lists and who do not want to be institutionalized
}

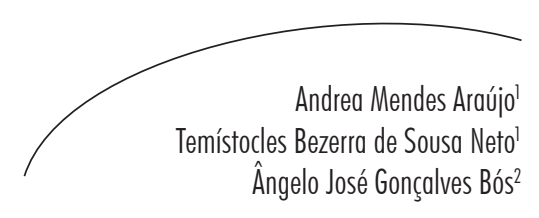

Abstract

Objective: To identify the demographic, environmental, economic, functional, and health characteristics and the lifestyle habits of elderly persons considering their degree of institutionalization. Method: A cross-sectional observational study was carried out of individuals in long-term care institutions for the elderly (resident group) in João Pessoa in the state of Paraíba, those on the waiting list (waiting list group) for such institutions, and those who did not demonstrate interest in being institutionalized (non-waiting list group). Fifty elderly persons per group were interviewed, paired by sex, age and education level. Results: The non-waiting list group had a higher proportion of married individuals $(p<0.0001)$, mean number of children $(p=0.0068)$, number of homeowners $(p=0.0060)$ and less difficulty going out, with a higher frequency of activities. The waiting list group presented a higher proportion of individuals living alone $(p=0.0089)$, and a lower frequency and more difficulty going out. There was no significant difference in the functional capacity of the three groups $(p=0.2019)$. Conclusion: There were differences among the three groups; however, the waiting list group had much more similar characteristics to the resident group than the non-waiting list group. Elderly persons on waiting lists to be institutionalized represent a neglected social group both in terms of research and public policies.

\footnotetext{
Universidade Federal da Paraíba, Centro de Ciências da Saúde, Escola Técnica de Saúde. João Pessoa, PB, Brasil.

2 Pontifícia Universidade Católica do Rio Grande do Sul, Instituto de Geriatria e Gerontologia, Programa de Pós-graduação em Gerontologia Biomédica. Porto Alegre, RS, Brasil.

Key words: Aging; Elderly; Family; Homes for the Aged; Waiting Lists. 


\section{INTRODUCTION}

The process of demographic transition brings with it considerable changes in the health profile of elderly persons, with greater numbers living with chronic diseases and functional incapacity. This results in higher levels of vulnerability and dependence and increasing demands on caregivers at the same as the number of family members available to perform this work declines. The family unit, which has culturally been the provider of care, is undergoing structural changes resulting from a fall in the birth rate $(1.77$ children on average per woman) and from changing patterns in marriage rates as well as the entry of women into the labor market. ${ }^{1,2}$

Among the alternatives for non-familial care of the elderly, the oldest and best known are nursing homes. This care model has always been viewed with resistance and prejudice, and the homes have been likened to "depositories for the elderly" and thought of as places for ending one's life. ${ }^{3}$ In Brazil, the terms asylum, shelter, nursing home and similar have been replaced with the term Instituição de Longa Permanência para Idosos, or Long-term Care Institutions for the Elderly (LTCIE), an expression adopted by the Sociedade Brasileira de Geriatria e Gerontologia (the Brazilian Society of Geriatrics and Gerontology) (SBGG).

With the process of aging, there is an increasing demand for LTCIEs, considered as alternative housing, ${ }^{4-6}$ and a form of health care. ${ }^{7}$ The coverage of this mode of living is lacking, however, perhaps reflecting the negative image that institutionalization produces. ${ }^{8}$ There is a conception that an elderly person only takes up residence in an LTCIE after having exhausted all other housing possibilities, and that it necessitates suffering on their part, ${ }^{9}$ a reality that is challenged when one observes daily life in the institutions and the reports of residents who are satisfied in their new homes..$^{10}$ Studies of institutionalization of the elderly overlook data from a considerable portion of this population, those on waiting lists for a place in an LTCIE. While there are occasional mentions of the existence of such individuals, ${ }^{5,6}$ no description of this population group was found in Brazilian literature.

Considering the unique characteristics of the institutionalized elderly, the lack of studies addressing the issue of the percentage of the population on the waiting list, in addition to the possibility of discovering characteristics that represent precursors for institutionalization, justify the purpose of this study, as there is a need to discuss and formulate new concepts regarding the institutionalization of the elderly in Brazil. We intend to present society and public authorities with data derived from a differentiated approach to this portion of the elderly population, which has a tendency for rapid growth.

In view of this, the aim of the present study was to identify the demographic, socialenvironmental, economic, functional, health and lifestyle characteristics of the elderly, according to their level of institutionalization.

\section{METHOD}

A cross-sectional, analytical, observational and non-probabilistic study, was performed of elderly persons (age $\geq 60$ years) in the city of João Pessoa in the state of Paraíba.

This study considered levels of institutionalization, separated into three groups. The first group, made up of elderly residents of LTCIEs, was named the resident group; the second, made up of people on the waiting list for a place in an LTCIE, was entitled the waiting list group; and the third, labelled non-waiting list group, was made up of elderly persons who were not on a waiting list and demonstrated no interest in residing in an LTCIE.

In addition to the inclusion criteria for age, study and cognitive functions adopted for the three groups, the following individual criteria were used: for the resident group - residence in an LTCIE in the city of João Pessoa for at least six months; for the waiting list group - inclusion on a waiting list for residence in an LTCIE in the period from January 
2010 to December 2012; and for the non-waiting list group, not being part of such a waiting list and not showing any interest in taking up residence in an LTCIE (the presence of interest was based on the person responsible for making a decision for each elderly person, whether a family member or the individual themselves).

To achieve the proposed aims of the study, strategies were adopted that could express the reality of the study groups and minimize the occurrence of bias. Therefore, the following pairing criteria were accepted with reference to the waiting list group: same gender; same age or a maximum difference of three years; same education level or a variation of one year of study.

The elderly population awaiting a place in an LTCIE was taken from the waiting list obtained from the LTCIEs in the city of João Pessoa. The search returned 690 requests for places, from which 409 persons were contacted by telephone (70 elderly persons had requested places at more than one institution). A total of 58 home visits were approved, while eight elderly people who did not have sufficiently preserved cognitive functions to respond to the survey questionnaire.

Access to the waiting list group of elderly people was made through telephone calls in which the purpose of the contact was explained beforehand. If the potential resident demonstrated sufficient cognition, authorization for a home visit was requested from the person responsible and/or the elderly person themselves.

The recruitment of the non-waiting list group was concomitant to that of the waiting list group. For each respondent of this group, a respondent from the non-waiting list group was sought on the same street or neighborhood, with similar characteristics to the individual in the waiting list group, in accordance with the pairing criteria. At first it was requested that each respondent from the waiting list group suggest another elderly person in the same street or neighborhood. Where it was impossible to locate someone using the initial respondent's information, the interviewers searched for a candidate using a home survey. Help was not sought from churches, resident associations or any other entities, in order to avoid bias in the sample.

As for the LTCIE resident group, for each 10 interviews in the community (five non-waiting + five from the waiting list), five interviews were held in the same LTCIE in which the respondents from the waiting list group had requested a place. Elderly residents were identified through the records of the institutions.

During data collection, which took place between the months of May 2012 and February 2013, the following instruments were utilized: the Mini Mental State Examination, in order to assess cognitive function, considering 18 as the cut off point for illiterate elderly persons, and 24 for those with one or more year of study; ${ }^{11}$ the Katz scale for assessing independence for the performance of Activities of Daily Living (ADLs), with the sample divided into dependent individuals (0-4 points) and independent individuals (5-6 points) ${ }^{12}$ and a questionnaire prepared by the authors of the study to obtain the following data: demographic (gender, ethnicity, age, education), social environment (marital status, number of children, type of residence, whether the individual lived alone and reasons for residing or wanting to reside in an LTCIE), economic (income and economic participation in family income), lifestyle habits (activities performed, frequency of leaving house, and number of daily meals) and clinical (presence of chronic/degenerative diseases or health impairments).

Prior to data collection, a pilot study was conducted aimed at adjusting the assessment tools and the operation of the collection phase. Six elderly persons participated, two respondents for each group, representative of the populations to be studied (resident, waiting list and non-waiting list). These individuals were not included in the study.

The data was organized in a database using the Epi Info program version 3.5.3, and was analyzed using descriptive and analytical statistics, with the results distributed in tables. 
For data analysis, the study groups were initially characterized using the following variables: demographic, socio-environmental, economic, functional, health and lifestyle habits. These were tabulated and distributed using frequency and percentages for the three study groups, arranged into tables, except for the variables of age, education, frequency of leaving house and number of children, which had their averages calculated and compared between groups. Possible differences in frequency and averages were tested using the Chi-squared test and the ANOVA (analysis of variance) test, respectively. When the variance of each group was not homogenous enough for the use of the same test, the non-parametric Kruskal-Wallis test was used to measure possible difference between the groups.

Homogeneity of variances of numerical variables was observed using the Bartlett test. When this was significant $(p<0.05)$, the non-parametric KruskalWallis test was used in place of ANOVA. Unlike ANOVA, which tests the difference between averages, this test evaluates whether the samples derive from the same distribution.

Tests with $p<0.05$ were considered as significant (an alpha type error of 5\%).
The study was approved by Research Ethics Committee of the Centro de Ciências da Saúde da Universidade Federal da Paraíba - CEP/ CS/UFPB, under registration no. 17123 dated 02/05/2012. All participants signed a Free and Informed Consent Form.

\section{RESULTS}

This study included 150 elderly people, equally distributed according to level of institutionalization into three groups: resident (50), waiting list (50) and non-waiting list (50). Table 1 shows the pairing criteria, where $100 \%$ of respondents from the resident group and $92 \%$ of the waiting list and nonwaiting list groups ( $p=0.1209)$ were located in the city of João Pessoa; $76 \%$ ( $p=1.0000)$ of the three groups were women, the average age between the groups varied by a maximum of 2.5 years $(\mathrm{p}=0.2166)$, and years of study ranged from 6.3 in the resident group to 7.2 for the non-resident group $(p=0.7002)$. There was no statistical difference between the groups for these variables, given that pairing criteria were used in the selection of the sample.

Table 1. Distribution of elderly individuals in relation to pairing criteria. João Pessoa, PB, 2012-2013.

\begin{tabular}{lcccc}
\hline & \multicolumn{3}{c}{ Groups } & p \\
\cline { 2 - 4 } \multicolumn{1}{c}{ Variables } & $\begin{array}{c}\text { Resident } \\
(\mathrm{n}=50)\end{array}$ & $\begin{array}{c}\text { Waiting list } \\
(\mathrm{n}=50)\end{array}$ & $\begin{array}{c}\text { Non-waiting list } \\
(\mathrm{n}=50)\end{array}$ & \\
\hline $\begin{array}{l}\text { City } \\
\text { João Pessoa }\end{array}$ & $50(100.0 \%)$ & $46(92.0 \%)$ & $46(92.0 \%)$ & 0.1209 \\
$\begin{array}{l}\text { Gender } \\
\text { Female }\end{array}$ & $38(76.0 \%)$ & $38(76.0 \%)$ & $38(76.0 \%)$ & \\
$\quad$ Male & $12(33.3 \%)$ & $12(33.3 \%)$ & $12(33.3 \%)$ & 1.0000 \\
Age $^{*}$ & $78.5( \pm 7.51)$ & $76.4( \pm 8.49)$ & $76.0( \pm 7.19)$ & 0.2166 \\
Years of study $^{*}$ & $6.3( \pm 4.77)$ & $6.8( \pm 5.64)$ & $7.2( \pm 4.91)$ & 0.7002 \\
\hline
\end{tabular}

* Average and standard deviation.

Table 2 shows the distribution of elderly individuals in terms of demographic and economic characteristics, according to group. In the resident group $52 \%$ were Caucasian, while in the waiting list and non-waiting list groups $60 \%$ and $56 \%$ respectively were mixed-race. As for monthly 
income, there was an indication of significance in the distribution of income levels among the three groups $(p=0.0882)$. Most of the resident group had an income of less than the minimum salary, while the waiting list group presented the highest proportion of elderly persons with a monthly income of three times the minimum wage or more. As for economic participation in family income, $56 \%$ of the waiting list group participated, while $70 \%$ of the non-waiting list group were responsible solely or in the majority for meeting the family's financial needs. The resident group was not asked about participation in family income.

Table 2. Distribution of elderly individuals in relation to demographic and economic characteristics, according to group. João Pessoa. PB. 2012-2013.

\begin{tabular}{|c|c|c|c|c|c|c|}
\hline \multirow[b]{2}{*}{ Characteristics } & \multicolumn{3}{|c|}{ Groups } & \multicolumn{3}{|c|}{$\mathrm{p}$} \\
\hline & $\begin{array}{l}\text { Resident } \\
(\mathrm{n}=50)\end{array}$ & $\begin{array}{c}\text { Waiting } \\
\text { list } \\
(\mathrm{n}=50)\end{array}$ & $\begin{array}{c}\text { Non-waiting } \\
\text { list } \\
(\mathrm{n}=50)\end{array}$ & All & $\begin{array}{l}\text { Waiting } \\
\text { list/ } \\
\text { Resident }\end{array}$ & $\begin{array}{c}\text { Waiting / } \\
\text { Non-waiting } \\
\text { list }\end{array}$ \\
\hline \multicolumn{7}{|l|}{ Ethnicity } \\
\hline Asian Brazilian & $0(0.0 \%)$ & $2(4.0 \%)$ & $2(4.0 \%)$ & \multirow{4}{*}{0.3138} & \multirow{4}{*}{0.1357} & \multirow{4}{*}{0.9338} \\
\hline Caucasian & $26(52.0 \%)$ & $17(34.0 \%)$ & $18(36.0 \%)$ & & & \\
\hline Mixed-race & $24(48.0 \%)$ & $30(60.0 \%)$ & $28(56.0 \%)$ & & & \\
\hline Afro Brazilian & $0(0.0 \%)$ & $1(2.0 \%)$ & $2(4.0 \%)$ & & & \\
\hline \multicolumn{7}{|l|}{ Elderly income } \\
\hline Up to $1 \mathrm{MS}$ & $31(62.0 \%)$ & $22(44.0 \%)$ & $22(44.0 \%)$ & \multirow{3}{*}{$0.0882^{*}$} & \multirow{3}{*}{0.0986} & \multirow{3}{*}{0.4902} \\
\hline$>1$ to $2 \mathrm{MS}$ & $14(28.0 \%)$ & $13(26.0 \%)$ & $18(36.0 \%)$ & & & \\
\hline $3 \mathrm{MS}$ or more & $5(10.0 \%)$ & $15(30.0 \%)$ & $10(20.0 \%)$ & & & \\
\hline \multicolumn{7}{|l|}{$\begin{array}{l}\text { Economic participation } \\
\text { in family income }\end{array}$} \\
\hline $\begin{array}{l}\text { Not participating or } \\
\text { divide responsibility }\end{array}$ & - & $22(44.0 \%)$ & $15(30.0 \%)$ & \multirow[t]{2}{*}{-} & \multirow[b]{2}{*}{-} & \multirow[b]{2}{*}{0.1470} \\
\hline $\begin{array}{l}\text { Main or sole } \\
\text { person responsible }\end{array}$ & - & $28(56.0 \%)$ & $35(70.0 \%)$ & & & \\
\hline
\end{tabular}

* Kruskal-Wallis test; MS= minimum salary.

Table 3 shows the distribution of elderly persons in terms of socio-environmental characteristics, according to group. With regards to marital status, there was a higher frequency of single people and widows/widowers in the resident and waiting list groups, with the non-waiting list group represented mainly by widowed and married $(p<0.0001)$ individuals.

Regarding number of children, most of the resident group respondents had no offspring. Most of the waiting list group, meanwhile, had between one and three children, while in the non-waiting list group there was a higher frequency of individuals with four or more children $(p<0.0001)$. In the selection from the waiting list and non-waiting list groups significant differences were found regarding the variables of marital status $(p=0.0003)$ and number of children $(p=0.0068)$.

The majority of the waiting list and non-waiting list groups lived in their own homes $(72 \%)$. As for the resident group, none lived in their own home as all resided in an LTCIE $(p<0.0001)$. As for living 
alone, most of the waiting list group and the vast majority of the non-waiting list group reported not living alone. This option was also cited by all of the resident group $(p<0.0001)$.

Among the reasons given for living in an LTCIE from both the resident and waiting list groups, and among the likely reasons that respondents from the non-waiting list group gave for requesting a vacancy, those cited most frequently were: lack of caregiver ( $p=0.0003)$ and request by family members ( $p=0.0158)$. Among the resident and waiting list groups the motives of personal choice and lack of caregiver were cited in most cases, with no statistical difference arising between these two groups. The motive spend too much time alone was cited mostly by the resident group. A significant difference was observed between the three groups $(p<0.0001)$.

In the resident and waiting list groups, there was a significant difference in relation to the motive spend too much time alone $(\mathrm{p}=0.0003)$. There was also a significant difference between the waiting list and non-waiting list groups for all the motives, with the exception of living alone (Table 3).

Table 3. Distribution of elderly individuals in relation to socio-environmental characteristics, according to group. João Pessoa. PB. 2012-2013.

\begin{tabular}{|c|c|c|c|c|c|c|}
\hline \multirow[b]{2}{*}{ Characteristics } & \multicolumn{3}{|c|}{ Groups } & \multicolumn{3}{|c|}{$\mathrm{p}$} \\
\hline & $\begin{array}{c}\text { Resident } \\
(\mathrm{n}=50)\end{array}$ & $\begin{array}{l}\text { Waiting list } \\
\qquad(\mathrm{n}=50)\end{array}$ & $\begin{array}{c}\text { Non- } \\
\text { waiting list } \\
(\mathrm{n}=50)\end{array}$ & All & $\begin{array}{l}\text { Waiting/ } \\
\text { Resident }\end{array}$ & $\begin{array}{c}\text { Waiting list/ } \\
\text { Non-waiting } \\
\text { list- }\end{array}$ \\
\hline \multicolumn{7}{|l|}{ Marital status } \\
\hline Married & $2(4.0 \%)$ & $3(6.0 \%)$ & $21(42.0 \%)$ & \multirow{4}{*}{$<0.0001$} & \multirow{4}{*}{0.6232} & \multirow{4}{*}{0.0003} \\
\hline Divorced & $8(16.0 \%)$ & $12(24.0 \%)$ & $2(4.0 \%)$ & & & \\
\hline Single & $25(50.0 \%)$ & $17(33.3 \%)$ & $9(18.0 \%)$ & & & \\
\hline Widowed & $15(30.0 \%)$ & $18(36.0 \%)$ & $18(36.0 \%)$ & & & \\
\hline \multicolumn{7}{|l|}{ Number of children } \\
\hline None & $26(52.0 \%)$ & $16(32.0 \%)$ & $11(22.0 \%)$ & \multirow{3}{*}{0.0001} & \multirow{3}{*}{0.1201} & \multirow{3}{*}{0.0068} \\
\hline $1-3$ & $18(36.0 \%)$ & $24(48.0 \%)$ & $14(28.0 \%)$ & & & \\
\hline 4 or more & $6(12.0 \%)$ & $10(20.0 \%)$ & $25(50.0 \%)$ & & & \\
\hline \multicolumn{7}{|l|}{ Type of residence } \\
\hline Not own & $50(100.0 \%)$ & $32(64.0 \%)$ & $14(28.0 \%)$ & \multirow[t]{2}{*}{$<0.0001$} & \multirow[t]{2}{*}{$<0.0001$} & \multirow[t]{2}{*}{0.0060} \\
\hline Own & $0(0.0 \%)$ & $18(36.0 \%)$ & $36(72.0 \%)$ & & & \\
\hline \multicolumn{7}{|l|}{ Live alone } \\
\hline No & $50(100.0 \%)$ & $33(66.0 \%)$ & $44(88.0 \%)$ & \multirow[t]{2}{*}{$<0.0001$} & \multirow[t]{2}{*}{$<0.0001$} & \multirow[t]{2}{*}{0.0089} \\
\hline Yes & $0(0.0 \%)$ & $17(34.0 \%)$ & $6(12.0 \%)$ & & & \\
\hline \multicolumn{7}{|l|}{$\begin{array}{l}\text { Motives for living } \\
\text { In an LTCIE }\end{array}$} \\
\hline Lack of caregiver & $20(40.0 \%)$ & $24(48.0 \%)$ & $6(12.0 \%)$ & 0.0003 & 0.4203 & $<0.0001$ \\
\hline No reason & $0(0.0 \%)$ & $0(0.0 \%)$ & $38(76.0 \%)$ & $<0.0001$ & -- & $<0.0001$ \\
\hline Own choice & $29(58.0 \%)$ & $26(52.0 \%)$ & $1(1.8 \%)$ & $<0.0001$ & 0.5464 & $<0.0001$ \\
\hline Family request & $12(24.0 \%)$ & $17(34.0 \%)$ & $5(10.0 \%)$ & 0.0158 & 0.2705 & 0.0037 \\
\hline Time Spent Alone & $26(52.0 \%)$ & $9(18.0 \%)$ & $3(6.0 \%)$ & $<0.0001$ & 0.0003 & 0.0648 \\
\hline
\end{tabular}

$p<0.05=$ significant. 
In table 4 the distribution of the elderly individuals in terms of matters of health and lifestyle habits can be seen, according to group. The diseases reported by respondents from the three groups were: arthritis ( $p=0.9704)$, depression ( $p=0.4642)$ and osteoporosis $(p=0.4386)$, intestinal problems $(p=0.0282)$ and, in the majority of respondents, hypertension ( $p=0.3397)$. As for eye problems $(p=0.0287)$, this issue was cited by the majority of respondents from the waiting list group.

There was a statistically significant difference between the waiting list and resident groups for intestinal problems $(p=0.0252)$, and eye problems ( $p$ $=0.0163$ ), while there was a statistically significant difference between the waiting list and non-waiting list groups for eye problems $(p=0.0275)$.

In the resident group, almost all respondents reported having four meals or more per day, as did the vast majority of the non-waiting list group and most of the waiting list group ( $p=0.0184$ ). A statistical difference was found between the waiting list and resident groups $(\mathrm{p}=0.0029)$.

Table 4 displays the frequency with which the elderly people leave the house (number of times per week) presenting an average and standard deviation of: 1.9 ( \pm 8.40$)$ for the resident group; 5.6 $( \pm 11.16)$ for the waiting list group and $17.7( \pm 16.14)$ for the non-waiting list group $(\mathrm{p}<0.0001)$. A statistically significant difference was also observed between the waiting list and non-waiting list groups for this variable $(p=0.0009)$. Among the difficulties described with regards to leaving the house, those that were statistically significant for all three groups were: difficulties with movement $(p=0.0029)$, lack of company $(p<0.0001)$ and difficulties with public transport $(p=0.0175)$.

Statistical differences were found in the activities currently performed by the respondents from the three groups, with the differences in the number of elderly persons participating religious activities $(p=0.0140)$, leisure activities $(p<0.0001)$ and domestic activities $(p=0.0003)$ proving to be significant. The differences between the groups for these activities were also significant, with the exception of domestic activities in the waiting list and non-waiting list groups ( $p=0.8399)$, as shown in Table 4.

Table 5 shows the distribution of the elderly persons with regard to functional characteristics and the groups studied. The functionality of the elderly persons was evaluated using the Katz Scale, where the vast majority of elderly individuals in the resident group and almost all the participants of the waiting list and non-waiting list groups possessed independence for carrying out ADLs, with no statistically significant difference between the groups $(p=0.2019)$.

Table 4. Distribution of elderly individuals in relation to the aspects of health and lifestyle habits, according to group. João Pessoa. PB. 2012-2013.

\begin{tabular}{ccccccc}
\hline & \multicolumn{3}{c}{ Groups } & \multicolumn{2}{c}{$p$} & \\
\cline { 2 - 7 } Characteristics & $\begin{array}{c}\text { Resident } \\
(\mathrm{n}=50)\end{array}$ & $\begin{array}{c}\text { Waiting list } \\
(\mathrm{n}=50)\end{array}$ & $\begin{array}{c}\text { Non-waiting } \\
\text { list }(\mathrm{n}=50)\end{array}$ & $\begin{array}{c}\text { Waiting } \\
\text { list/ } \\
\text { Resident }\end{array}$ & $\begin{array}{c}\text { Waiting list/ } \\
\text { Non-waiting } \\
\text { list }\end{array}$ \\
\hline Number of daily meals & & & & & & \\
Less than four & $4(8.0 \%)$ & $15(30.0 \%)$ & $9(18.0 \%)$ & $\mathbf{0 . 0 1 8 4}$ & $\mathbf{0 . 0 0 2 9}$ & 0.3310 \\
Four or more & $46(92.0 \%)$ & $35(70.0 \%)$ & $41(82.0 \%)$ & & & \\
Activities carried out & & & & & & \\
Religious activities & $23(46.0 \%)$ & $13(26.0 \%)$ & $27(54.0 \%)$ & $\mathbf{0 . 0 1 4 0}$ & $\mathbf{0 . 0 3 7 2}$ & $\mathbf{0 . 0 0 4 2}$ \\
Leisure activities & $36(72.0 \%)$ & $9(18.0 \%)$ & $32(64.0 \%)$ & $<\mathbf{0 . 0 0 0 1}$ & $<\mathbf{0 . 0 0 0 1}$ & $<\mathbf{0 . 0 0 0 1}$ \\
Domestic activities & $22(44.0 \%)$ & $21(42.0 \%)$ & $39(78.0 \%)$ & $\mathbf{0 . 0 0 0 3}$ & 0.8399 & $\mathbf{0 . 0 0 0 2}$
\end{tabular}




\begin{tabular}{|c|c|c|c|c|c|c|}
\hline \multirow[b]{2}{*}{ Characteristics } & \multicolumn{3}{|c|}{ Groups } & \multicolumn{3}{|c|}{$p$} \\
\hline & $\begin{array}{l}\text { Resident } \\
(\mathrm{n}=50)\end{array}$ & $\begin{array}{l}\text { Waiting list } \\
\qquad(\mathrm{n}=50)\end{array}$ & $\begin{array}{l}\text { Non-waiting } \\
\text { list }(n=50)\end{array}$ & All & $\begin{array}{l}\text { Waiting } \\
\text { list/ } \\
\text { Resident }\end{array}$ & $\begin{array}{c}\text { Waiting list/ } \\
\text { Non-waiting } \\
\text { list }\end{array}$ \\
\hline $\begin{array}{l}\text { Frequency of leaving } \\
\text { the house* }\end{array}$ & $1.9( \pm 8.40)$ & $5.6( \pm 11.16)$ & $17.7( \pm 16.14)$ & $<0.0001$ & 0.1370 & 0.0009 \\
\hline \multicolumn{7}{|l|}{$\begin{array}{l}\text { Difficulties in } \\
\text { leaving the house }\end{array}$} \\
\hline $\begin{array}{l}\text { Difficulties with } \\
\text { movement }\end{array}$ & $23(46.0 \%)$ & $33(66.0 \%)$ & $16(32.0 \%)$ & 0.0029 & 0.0439 & 0.0006 \\
\hline Lack of company & $29(58.0 \%)$ & $17(34.0 \%)$ & $4(8.0 \%)$ & $<0.0001$ & 0.0160 & 0.0014 \\
\hline $\begin{array}{l}\text { Difficulties with } \\
\text { Public transport }\end{array}$ & $6(12.0 \%)$ & $10(20.0 \%)$ & $1(2.0 \%)$ & 0.0175 & 0.2752 & 0.0040 \\
\hline $\begin{array}{l}\text { No difficulties } \\
\text { observed }\end{array}$ & $8(16.0 \%)$ & $10(20.0 \%)$ & $21(42.0 \%)$ & 0.0061 & 0.6026 & 0.0173 \\
\hline \multicolumn{7}{|l|}{ Diseases } \\
\hline Arthritis & $17(34.0 \%)$ & $16(32.0 \%)$ & $17(34.0 \%)$ & 0.9704 & 0.8315 & 0.8315 \\
\hline Depression & $14(28.0 \%)$ & $13(26.0 \%)$ & $9(18.0 \%)$ & 0.4642 & 0.8217 & 0.3342 \\
\hline Diabetes & $8(16.0 \%)$ & $6(12.0 \%)$ & $5(10.0 \%)$ & 0.6558 & 0.5643 & 0.7492 \\
\hline Hypertension & $36(72.0 \%)$ & $32(64.0 \%)$ & $29(58.0 \%)$ & 0.3397 & 0.3911 & 0.5385 \\
\hline Osteoporosis & $14(28.0 \%)$ & $20(40.0 \%)$ & $18(36.0 \%)$ & 0.4386 & 0.2052 & 0.6803 \\
\hline Intestinal problems & $2(4.0 \%)$ & $9(18.0 \%)$ & $11(22.0 \%)$ & 0.0282 & 0.0252 & 0.6170 \\
\hline Eye problems & $20(40.0 \%)$ & $32(64.0 \%)$ & $21(42.0 \%)$ & 0.0287 & 0.0163 & 0.0275 \\
\hline
\end{tabular}

$p<0.05=$ significant; $*$ average and standard deviation.

Table 5. Distribution of elderly individuals in relation to the functional characteristics through assessment of activities of daily living (ADL) according to group. João Pessoa, PB, 2012-2013.

\begin{tabular}{lcccc}
\hline & \multicolumn{4}{c}{ Groups } \\
\cline { 2 - 5 } & $\begin{array}{c}\text { Resident } \\
(\mathrm{n}=50)\end{array}$ & $\begin{array}{c}\text { Waiting list } \\
(\mathrm{n}=50)\end{array}$ & $\begin{array}{c}\text { Non-waiting list } \\
(\mathrm{n}=50)\end{array}$ & $p$ \\
\hline ADL & & & \\
Dependence & $7(14.0 \%)$ & $4(8.0 \%)$ & $2(4.0 \%)$ & 0.2019 \\
Independence & $43(86.0 \%)$ & $46(92.0 \%)$ & $48(96.0 \%)$ & \\
\hline
\end{tabular}




\section{DISCUSSION}

The present study included groups of elderly persons placed in different social contexts. Women predominated, corroborating the findings of other studies which have presented demographic aspects of the institutionalized and non-institutionalized elderly population. ${ }^{6,8,13-17}$ The proportion of women on waiting lists before the exclusion criteria were adopted for this survey was $64 \%$, higher than the proportion of females in the elderly Brazilian population, which is $55.8 \%,{ }^{17}$ reflecting cultural and familial structure factors. Culturally, women are more involved with caring, visit Family Health Units most often ${ }^{18}$ and are also less likely to have a second family after divorce/separation or widowhood. As this is the first study of the profile of elderly persons on waiting lists for LTCIEs, no data is available from other studies for possible comparisons.

Among the exclusion criteria adopted for this research, it was observed that a higher proportion of men refused to participate in this study, leading to the assumption that the need for a place in an LTCIE arises among men mainly when all possibilities for residence outside an institution have been exhausted. This situation is not as common among women, who during the interviews demonstrated more concern about their future care, due to a greater predisposition for widowhood and/or being unmarried or single, as opposed to men, who find it easier to marry and remarry.

Another important factor which was highlighted in the interviews was the wish expressed by women that they not be a burden on their children or an obstacle to their familial or career advancement. Widowhood and the desire not to cause extra work for relatives are among the motives for the institutionalization of the elderly. ${ }^{19}$ Herédia et al. ${ }^{20}$ described the desire of elderly persons not to cause extra work for their children.

Average age was not significantly different among the three groups. The highest average was observed in the group of institutionalized elderly, agreeing with other studies. ${ }^{13,14,21-23}$ Although pairing was carried out, there was a difficulty in identifying participants with ages close to those in the waiting list group, particularly among those in the resident group. This shows that the search for an LTCIE place occurs at an early stage. In some interviews, there was a desire to guarantee a place before evidence of disability had arisen, demonstrating concern with the provision of future care.

Education was the third and final criteria adopted for the pairing of the sample, where the average number of years of study of LTCIE residents was observed to be lower than that of elderly persons in the community (waiting list and non-waiting list), although this was not a statistically significant difference $(p=0.7002)$. Oliveira \& Novaes ${ }^{21}$ in a survey of elderly people living in an LTCIE in Brasilia, reported an average educational level of seven years of study. The majority of other studies have found averages lower than this., ${ }^{6,13,14,16}$ According to Mincato \& Freitas, ${ }^{6}$ this fact may reflect an era when educational programs were more limited and there were higher levels of exclusion of access to basic education, especially among women.

Since 2003, the Ministério da Educação (Ministry of Education), through the program "Brasil Alfabetizado" (Literate Brazil), has aimed to eradicate illiteracy and contribute to the universalization of primary education in Brazil, with the elderly also benefitting. ${ }^{23}$ However, there is no evidence of the actions of this program benefiting LTCIE residents. This is believed to be due to the negative stigma attached to such services, namely that they are used only by physically and mentally disabled elderly persons.

Regarding the other variables examined for the groups studied, a monthly income of less than the minimum wage was declared by individuals from the sample across all three groups, corresponding to the reality faced by the majority of older people according to Brazilian statistics. ${ }^{24}$ Other studies of the institutionalized elderly also cite the low income levels found in the majority of residents..$^{16,25,26}$ 
The significant number of elderly people in the waiting list group who received three times the minimum wage or more also deserves highlighting. Compared with the resident group, a greater number of people with better financial conditions opted for residence in LTCIEs.

According to Camarano \& Melo, ${ }^{27}$ members of this population experience moments of profound change in the family environment, such as increasing violence, especially against the elderly person themselves, the fragility inherent in the aging process and the lack of organization of adequate services to meet the demands of longevity among the community. This causes people, even those who could afford a formal caregiver at home, to seek out LTCIEs, due to the provision of formal care, tranquility (away from family conflicts) and security.

As regards economic participation in family income, the majority of elderly individuals in the non-waiting list group were the largest or sole provider for household income. According to data from the Instituto Brasileiro de Geografia e Estatística (the Brazilian Institute of Geography and Statistics) (IBGE), in 2009, elderly persons held the position of head of household in 64.1\% of Brazilian homes. ${ }^{17}$ The non-waiting list group also contained the largest number of older people living in their own home, a total that was significantly different from the other groups.

Statistical differences were also found in marital status between the groups, among elderly persons who were divorced/separated, unmarried and widows/widowers. These differences were prevalent in the resident and waiting list groups, with other studies of the institutionalized elderly corroborating these findings..$^{6,8,13}$

In a comparison of the waiting list and nonwaiting list groups, the non-waiting list group contained the highest number of married participants, participants who left the house more often and those who had a higher number of children (four or more). It can be assumed that the fact of being married and having more offspring to provide care generates, in the elderly, the comfort of having future care needs met by their own families, with the provision of this care divided among relatives. Moreover, as stated by Duca et al. ${ }^{13}$ the presence of a spouse in daily activities and social relations contributes to improvements in the self-esteem and autonomy of the elderly.

The number of married persons among the resident group, although few in number, occurred when both spouses were living in an institution, but in separate rooms and wards, as the institutions have male and female wards, showing that they were not designed for this situation. The same phenomenon was also observed in the waiting list group, where there were couples on the waiting list, who were aware of and willing to conform with institutional rules.

The number of children of individuals in the waiting list group differed from those in the resident group, with childlessness most common among the institutionalized elderly. A preoccupation with avoiding becoming a burden upon families, and of not being a hindrance amidst the demands of modern life, exists amongst the elderly. Bearing out this fact, the majority of individuals in the waiting list group chose to request LTCIE vacancies themselves. Also evident is the concern of the elderly about their future care and the search for improvements in the situation in which they find themselves. Rodrigues ${ }^{19}$ in his dissertation entitled: The Satisfaction With Life Of Institutionalized Elderly Persons, makes reference to the concern of elderly individuals with the risk of becoming a burden on their families.

One of the most cited motives among respondents from the resident group was lack of a caregiver, conforming to findings from other studies. ${ }^{20,28}$ This was also a reason which respondents from the non-waiting list group said might lead them to request a vacancy in an LTCIE, and also represented the motive most commonly cited by respondents from the waiting list group. The provision of training for caregivers of the elderly is part of the Ministério da Saúde (Ministry of Health) agenda, which prioritizes home care, suggesting that this should be offered by relatives, close friends or neighbours. ${ }^{27}$ 
The complexity of care and the psychological burden on the caregiver require different strategies in addition to training, such as: monitoring, support from Unidades de Saúde da Família (Family Health Units), Núcleos de Apoio à Saúde da Família (Family Health Support Centers) and scheduled days off, among other incentives that might favor home care.

Regarding Family Health Strategies (FHS), Camarano \& $\mathrm{Mello}^{27}$ report that, although they are considered to be one of the first public policies to support vulnerable families, there is no knowledge of specific guidelines for care for the elderly, and much less for institutional care.

According to the Estatuto do Idoso (Elderly Statute) (article 18), health institutions must meet the minimum criteria for attending to the needs of elderly people, promoting the training of professionals and providing guidance to family caregivers and self-help groups. ${ }^{29}$ Health teams are considered to be an important strategy in health promotion and disease prevention, as well as guiding home caregivers, and their actions must go beyond the promotion of active and healthy aging.

In the waiting list group, most respondents did not reside alone, however the significant number of this group who did live alone should be highlighted, nearly triple the number of respondents from the non-waiting list group in the same situation. Studies point to living alone as one of the key motives for institutionalization. ${ }^{13,15,20,25}$

Regarding the activities carried out by the elderly, there was a similarity between the resident and non-waiting list groups, with more elderly people performing religious, leisure and household activities, differing significantly from the waiting list group. According to Duca et al., ${ }^{30}$ inactivity contributes to physical and mental impairment and, therefore, accelerates the need for long-term care. Dias et al. ${ }^{31}$ emphasize the need to connect activities to the desire and ability of each person, so they can be more pleasurable and healthy.

As a person ages, many tasks previously considered easy to perform will gradually increase in difficulty, ${ }^{30}$ and environmental conditions are rarely suitable for the performance of safe activities in this phase of life. The simple act of leaving the house can cause suffering for an elderly person, caused by the degree of difficulty that this activity can present. The obstacles to leaving the house most often cited by respondents in the waiting list group were limited mobility, lack of security and lack of companionship. A large part of the nonwaiting list group reported no difficulties, with the reason possibly lying in the support network from which this group benefits.

A healthy diet, with four or more daily meals, was a common feature of the resident and nonwaiting list groups, with a statistically significant difference among the three groups, and between comparisons of frequencies in the waiting list and resident groups for this variable. The difference is probably related to the care offered to the resident group in the LTCIE and to the non-waiting list group by their families, which was more structured. According to Camarano \& Kanso, ${ }^{1}$ family care is critical to the welfare of the elderly.

Aging is associated with the onset of chronic diseases, with risk increasing along with age. In people aged 75 years or more, the probability of having a disease is $54 \%$, according to IBGE data IBGE. ${ }^{17}$ According to Veras ${ }^{32}$ non-communicable chronic diseases constitute a serious public health problem, with their increased prevalence related to higher life expectancy, changes in eating habits and increased physical inactivity and stress.

Among the principal chronic diseases that affect elderly Brazilians, hypertension is the most prevalent, affecting $58.9 \%$ of men and $66.6 \%$ of women, while others diseases cited by the IBGE were arthritis and rheumatism, back problems and heart diseases. ${ }^{17}$ This national data corroborates part of the findings common to the three groups in this survey, which reported hypertension, osteoporosis, arthritis and diabetes. Depression was cited most by individuals in the resident and waiting list groups, and is considered to be one of the most common disorders to affect the elderly. ${ }^{22}$ For Hoffmann et al., ${ }^{33}$ functional incapacity is 
strongly associated with the occurrence of this disease, and can significantly affect the quality of life of an individual.

As regards functional capacity among the groups, the majority of respondents in all three groups presented the independence necessary for carrying out basic daily activities as evaluated by the Katz Scale. There was no statistically significant difference between groups.

However, it is worth noting that the resident group had a higher percentage of respondents affected by functional disabilities, corroborating studies that describe institutionalized elderly persons with impaired functional capacity, this generally being attributed to physical inactivity, more advanced age $^{30}$ and their period of institutionalization. ${ }^{34}$

Among difficulties faced in the performance of ADLs, the most cited by respondents from the waiting list and resident groups were: bathing, dressing and bowel/bladder control. Studies cite bathing and dressing as the activities that the institutionalized elderly face most difficulties in performing. ${ }^{34}$

Those interviewed in the resident group may not have been representative of all residents of the surveyed institutions. The use of pairing meant that younger residents with less cognitive impairment were generally chosen, consequently being less dependent than the residents observed during visits to institutions.

Oliveira \& Novaes, ${ }^{21}$ surveyed 154 institutionalized elderly from the Distrito Federal (Federal District) in Brazil, divided into two groups, one selected with discernment and the other without. It was found that $83.2 \%$ of the former group displayed independence in the performance of basic daily activities. In the present study, the resident group presented a slightly higher percentage of functional capacity $(86.0 \%)$.

The number of elderly people on waiting lists in the city of João Pessoa is higher than that presented in this study, since most LTCIEs did not maintain reliable quantitative records. The institutions received many daily requests and were unable to reply to all of the people seeking help. Of the 50 respondents on a waiting list, only three had gained a place in an institution by October 2013. In further contact with these three people, it was possible to identify a clear change in their expressed degree of happiness.

As a limitation of the present study, selection bias was identified that prevented the analysis of possible differences in functional capacity between the three groups. Functional capacity was not an exclusion criterion adopted for the study, but it was necessary that participants had sufficient cognitive conditions in order to answer the proposed questionnaire. This criterion meant that there was a significant selection bias as to the ability of the participants in the sample from the waiting list group, and therefore also from the resident group.

Difficulties in accessing LTCIEs were also observed for elderly individuals in the waiting list group, for example: request forms for an LTCIE place that were out of date or not working (justification - to not give applicants false hope as the waiting list was already long); disconnected or non-existent phone numbers; phone numbers not known; family members who refused to talk about the issue; elderly individuals and/or family members who refused to receive visits; family members who denied the request for a place and, finally, death.

\section{CONCLUSION}

The three groups showed significant differences in many of their compared features. The waiting list group had values closer to those of the resident group. However, the waiting list group in comparison with the resident group presented greater difficulties with movement, lack of company, leaving the house and a lower frequency of leisure activities. It cannot be determined, using the proposed design, whether institutionalization can or cannot modify differences in these characteristics. It was also observed that the non-waiting list group had a higher proportion of individuals who were married, had higher numbers of children and lived in their own 
homes, with a lower proportion of individuals living alone.

People awaiting a place in a Long-term Care Institution for the Elderly represent a social group neglected both by research as well as public policy. The Política Nacional do Idoso (National Policy for the Elderly) (Law No. 8.842/1994) established services that could alleviate this suffering, for example residence in sheltered or communal housing or care in day-centers or community centers. ${ }^{35}$ However, there is a need for these services to form part of the daily life of the elderly population. In addition to a structured policy for these programs, not only in terms of monitoring, but also through technical support and adequate funding, there is a need for integration between different sectors of society in order to consolidate these actions. An example of the failures in the implementation of these services is the existence of just two community centers to serve a population of more than 74,000 elderly people. ${ }^{17}$

\section{REFERENCES}

1. Camarano AA, Kanso S. Como as famílias brasileiras estão lidando com idosos que demandam cuidados e quais as perspectivas futuras?: a visão mostrada pelas PNADS. In: Camarano AA. Cuidados de longa duração para a população idosa: um novo risco social a ser assumido? Rio de Janeiro: IPEA; 2010. p. 93-122.

2. Carvalho JAM, Garcia RA. O envelhecimento da população brasileira: um enfoque demográfico. Cad Saúde Pública 2003;19(3):725-33.

3. Camarano AA, Scharfstein EA. Instituição de longa permanência para idosos: abrigo ou retiro? In: Camarano, AA, organizador. Cuidados de longa duração para a população idosa: um novo risco social a ser assumido? Rio de Janeiro: IPEA; 2010. p. 163-86.

4. Pollo SHL, Assis M. Instituições de longa permanência para idosos - ILPIs: desafios e alternativas no município do Rio de Janeiro. Rev Bras Geriatr Gerontol 2008;11(1):29-43.

5. Polaro SHI, Fideralino JCT, Nunes PAO, Feitosa ES, Gonçalves LHT. Idosos residentes em instituições de longa permanência para idosos da região metropolitana de Belém-PA. Rev Bras Geriatr Gerontol 2012;15(4):777-84.

6. Mincato PC, Freitas CLR. Qualidade de vida dos idosos residentes em instituições asilares da cidade de Caxias do Sul-RS. Rev Bras Ciênc Envelh Hum 2007;4(1):127-38.

7. Oliveira ERA, Gomes MJ, Paiva KM.

Institucionalização e qualidade de vida de idosos da região metropolitana de Vitória-ES. Esc Anna Nery Enferm 2011;15(3):518-23.

8. Alencar MA, Bruck NNS, Pereira BC, Câmara TMM, Almeida RDS. Perfil dos idosos residentes em uma instituição de longa permanência. Rev Bras Geriatr Gerontol 2012;15(4):785-96.
9. Rissardo LK, Furlan MCR, Grandizolli G, Marcon SS, Carreira L. Sentimentos de residir em uma instituição de longa permanência: percepção de idosos asilados. Rev Enferm UERJ 2012; 20(3):380-5.

10. Carli L, Kolankiewicz ACB, Loro MM, Piovesan CLSR. Sentimentos e percepções de idosos residentes em uma instituição asilar. Rev Pesqui Cuid Fundam [Internet] 2012 [acesso em 4 mar. 2014];4(2):2868-77. Disponível em: http://www.seer.unirio.br/index.php/ cuidadofundamental/article/view/1726/pdf_509

11. Lourenço RA, Veras RP. Mini-exame do estado mental: características psicrométricas em idosos ambulatoriais. Rev Saúde Pública 2006;40(4):712-9.

12. Barrantes-Monge M, Garcia-Mayo EJ, GutierrezRobledo LM, Miguel JA. Dependencia funcional y enfermidades crônicas em ancianos mexicanos. Salud Publica Méx 2007;49(Supl 4):459-66.

13. Duca GFD, Silva SG, Thumé E, Santos IS, Hallal PC. Indicadores da institucionalização de idosos: estudos de casos e controles. Rev Saúde Pública 2012;46(1):147-53.

14. Grundy E, Jitlal M. Socio-demographic variations in moves to institutional care 1991-2001: a record linkage study from England and Wales. Age Ageing 2007;36(4):424-30.

15. Terra LT, Bós AJG, Bonardi G, Dickel CCM, Mohr CC, Mallmann L, et al. Diferenças biopsicossociais entre idosos de instituição asilar particular e filantrópica da cidade de Porto Alegre. Sci Med 2009;19(1):3-10.

16. Ângelo BHB, Silva DIB, Lima MAS. Avaliação das instituições de longa permanência para idosos no município de Olinda-PE. Rev Bras Geriatr Gerontol. 2011;14(40):663-73. 
17. Instituto Brasileiro de Geografia e Estatística [Internet]. Rio de Janeiro: IBGE, 1995- . Dados do censo IBGE 2010. 2010; [acesso em 19 jul. 2011]; [aproximadamente 2 telas]. Disponível em: http:// www.ibge.gov.br/home/

18. Nunes VMA, Meneses RMP, Alchieri JC. Avaliação da qualidade de vida em idosos institucionalizados no município de Natal, Estado do Rio Grande do Norte. Acta Sci Health Sci 2010;32(2):119-26.

19. Rodrigues SI. A satisfação com a vida de idosos institucionalizados [dissertação]. Coimbra: Instituto Superior Miguel Torga; 2011

20. Herédia VBM, Cortelleti IA, Casara MB. Institucionalização do idoso: identidade e realidade. In: Cortelleti IA, Casara MB, Herédia VBM. Idoso asilado: um estudo gerontológico. 2. ed. Porto Alegre: Edipucrs; 2010. p. 15-62.

21. Oliveira MPF, Novaes MRCG. Perfil socioeconômico, epidemiológico e farmacoterapêutico de idosos institucionalizados de Brasília, Brasil. Ciênc Saúde Coletiva 2013;18(4):1069-78.

22. Danilow MZ, Moreira ACS, Villela CG, Barra BB, Novaes MRCG, Oliveira MPF. Perfil epidemiológico e psicossocial de idosos institucionalizados do Distrito Federal. Comun Ciênc Saúde 2007;18(1):9-16.

23. Brasil. Ministério da Educação. Programa Brasil Alfabetizado [Internet]. Brasília, DF: MEC; 2013 [acesso em 19 set. 2013]. Disponível em:http://portal. mec.gov.br/

24. Batista ASB, Jaccoud LB, Aquino L, El-Moor PD. Envelhecimento e dependência: desafios para a organização da proteção social. Brasília, DF: MPS; 2008. p. 106-37.

25. Born T, Boechat NS. A qualidade dos cuidados ao idoso institucionalizado. In: Freitas Ev, Py L, editores. Tratado de geriatria e gerontologia. 3. ed. Rio de Janeiro: Guanabara Koogan; 2011
26. Michel T. A vivência em uma instituição de longa permanência: significados atribuídos pelos idosos [dissertação]. Curitiba: Universidade Federal do Paraná; 2010.

27. Camarano AA, Mello JL. Cuidados de longa duração no Brasil: arcabouço legal e as ações governamentais. In: Camarano AA. Cuidados de longa duração para a população idosa: um novo risco social a ser assumido? Rio de Janeiro: IPEA; 2010. p. 67-91.

28. Perlini NMOG, Leite MT, Furini AC. Em busca de uma instituição para a pessoa idosa morar: motivos apontados por familiares. Rev Esc Enferm USP 2007;41(2):229-36

29. Brasil. Ministério da Saúde. Estatuto do idoso. Brasília, DF: Ministério da Saúde; 2003.

30. Duca GFD, Silva MC, Silva SG, Nahas MV, Hallal PC. Incapacidade funcional em idosos institucionalizados. Rev Bras Ativ Fís Saúde 2011;16(2):120-4.

31. Dias DSG, Carvalho CS, Araújo CV. Comparação da percepção subjetiva de qualidade e bem-estar de idosos que vivem sozinhos, com a família e institucionalizados. Rev Bras Geriatr Gerontol 2013;16(1):127-38

32. Veras RP. Estratégias para o enfrentamento das doenças crônicas: um modelo em que todos ganham. Rev Bras Geriatr Gerontol 2011;14(4):779-86.

33. Hoffman EJ, Ribeiro F, Farnese JM, Lima EWB. Sintomas depressivos e fatores associados entre idosos residentes em uma comunidade no norte de Minas Gerais, Brasil. J Bras Psiquiatr 2010;59(3):190-97

34. Mazuim CHR. Idoso institucionalizado: suporte, abrigo ou segregação? Canoas: Ulbra; 2005.

35. Brasil. Ministério da Saúde. Política Nacional de Saúde da Pessoa Idosa [Internet]. Brasília, DF: Ministério da Saúde; 2006 [acesso em 20 maio 2011]. Disponível em: http://portal.saude.gov.br/ 